\title{
PENGARUH KOMUNIKASI EFEKTIF DAN PELAYANAN PRIMA BAGI WANITA UNTUK MELAKUKAN LATIHAN BEBAN
}

Oleh: Eka Novita Indra

Dosen Jurusan Pendidikan Kesehatan dan Rekreasi FIK UNY

Abstrak

Komunikasi adalah suatu kata yang mencakup segala bentuk interaksi dengan orang lain yang berupa percakapan biasa, membujuk, mengajar, dan negosiasi. Komponen utama proses komunikasi, yaitu: komunikator, pesan, dan komunikan, sedangkan secara umum bentuk komunikasi dibagi dalam dua bagian, yaitu: komunikasi verbal dan komunikasi nonverbal. Komunikasi efektif merupakan bagian dari pelayanan prima.

Pelayanan prima merupakan terjemahan dari istilah excellent service yang secara harafiah berarti pelayanan yang sangat baik, karena sesuai dengan standar pelayanan yang berlaku atau dimiliki oleh instansi yang memberikan pelayanan. Tujuan pelayanan prima adalah memberikan pelayanan yang sesuai dengan harapan dan dapat memuaskan konsumen.

Motivasi adalah segala sesuatu yang mendorong seseorang untuk melakukan sesuatu dengan tujuan tertentu, baik itu yang bersifat intrinsik maupun yang bersifat ekstrinsik. Pengaruh pelayanan prima dan komunikasi efektif cukup signifikan terhadap peningkatan motivasi ekstrinsik seorang khususnya wanita untuk bergabung dan mengikuti program latihan di klub kebugaran.

Kata kunci: komunikasi, pelayanan prima, motivasi

MEDIKOPA Vol. I, No. 2, Oktober 2005: 186-201. 
Olahraga yang sering kali dipandang hanya semata-mata dikaitkan dengan pertandingan, dewasa ini secara umum mengalami perkembangan yang cukup pesat dan kemajuan peradaban manusia memberi pengaruh yang positif pada peningkatan kualitas sumber daya manusia. Apabila ditinjau secara fisik tentu saja setiap orang ingin memiliki tubuh yang tidak hanya sehat, tetapi juga bugar agar dapat melakukan semua aktivitas secara aktif, dinamis, dan produktif.

Memiliki tubuh yang sehat dan bugar merupakan impian semua orang, tidak terkecuali para wanita dari segala umur dan lapisan sosial. Banyak cara untuk mendapatkannya, salah satunya adalah dengan melakukan latihan beban di klub kebugaran. Banyak orang yang berangapan bahwa latihan beban hanya dapat dilakukan oleh kaum pria. Pernyataan tersebut tidaklah benar, karena wanita juga dapat melakukan latihan beban. Selain dituntut untuk selalu aktif dan produktif, wanita juga dituntut untuk selalu tampil menarik, karena akan menambah rasa percaya diri. Apalagi masih banyak orang yang cenderung mengkorelasikan penampilan fisik dengan status sosial seseorang.

Berorientasi pada peningkatan kesadaran masyarakat akan kebutuhan hidup sehat, tentu saja membuka peluang bisnis, sehingga klub-klub kebugaran pun sangat mudah ditemukan di kota kecil sekalipun. Meningkatnya persaingan industri jasa kebugaran akhirnya memaksa pemasar jasa, dalam hal ini para pemilik klub kebugaran untuk lebih meningkatkan kepuasan para anggotanya sebagai konsumen dengan cara berlomba memberikan pelayanan yang terbaik.

Pelayanan pada dasarnya adalah kegiatan yang ditawarkan oleh suatu organisasi, perusahaan atau perorangan kepada pihak lain (konsumen). Motivasi eksternal seseorang dapat dibangun dengan adanya proses komunikasi efektif yang merupakan bagian dari pelayanan prima.

\section{KOMUNIKASI EFEKTIF}

Komunikasi secara etimologis berasal dari bahasa Latin cum, sebuah kata depan yang artinya dengan, atau bersama dengan, dan kata umus sebuah kata bilangan yang berarti satu. Dua kata tersebut membentuk kata benda communio/communion yang berarti kebersamaan, gabungan, atau hubungan.

Pengaruh Komunikasi Efektif dan Pelayanan Prima bagi Wanita ... (Eka Novitas Indra) 
Kata benda tersebut apabila diubah menjadi kata kerja communicare berarti membagi sesuatu dengan seseorang, tukar menukar, membicarakan sesuatu dengan seseorang, bercakap-cakap, bertukar pikiran, berhubungan, dan berteman. Apabila disimpulkan dari asal katanya komunikasi adalah pemberitahuan atau pembicaraan, percakapan, pertukaran pikiran atau hubungan seseorang dengan orang lain.

Dalam perkembangannya banyak ahli komunikasi memberikan definisi yang berbeda-beda. Beberapa pengertian komunikasi yang dikutip dari buku Komunikasi yang Efektif disajikan berikut ini:

1. Upaya untuk membuat pendapat, menyatakan perasaan, menyampaikan informasi dan sebagainya agar diketahui atau dipahami oleh orang lain.

2. Komunikasi adalah seluruh proses yang digunakan untuk mencapai pikiran-pikiran orang lain.

Masih banyak definisi selain yang dikemukakan di atas. Meskipun demikian, dari sekian banyak definisi yang ada dapat disarikan bahwa komunikasi adalah suatu kata yang mencakup segala bentuk interaksi dengan orang lain yang berupa percakapan biasa, membujuk, mengajar, dan negosiasi.

\section{Komponen-komponen Komunikasi}

Efektivitas dan efisiensi suatu proses komunikasi, sangat bergantung pada komponen-komponen yang terlibat di dalamnya. Setiap komponen tersebut memiliki peran dan fungsinya masing-masing. Berikut komponen utama proses komunikasi, yaitu:

1. Komunikator/sender/pengirim

Komunikator adalah seseorang yang memberikan/mengirim pesan. Komunikator memiliki peranan yang sangat penting di dalam proses komunikasi. Dalam klub kebugaran, misalnya instruktur merupakan salah satu ujung tombak untuk keberhasilan perusahaan penjual jasa tersebut. Instruktur harus dapat mempengaruhi anggotanya untuk memperoleh pengetahuan tentang olahraga dan kesehatan, mengubah sikap dan gaya hidup yang lebih sehat, atau perilaku anggota sehingga program latihan akan tercapai.

MEULCORA Vol. I, No. 2, Oktober 2005: 186-201. 
Oleh karenanya seorang instruktur harus selalu memperhatikan beberapa hal, yaitu: (1) kesiapan (preparedness), (2) kesungguhan (seriousness), (3) ketulusan (sincerity), (4) kepercayaan (confidence), (5) ketenangan (poise), (6) keramahan (friendship), dan (7) kesederhanaan (moderation).

2. Pesan $/$ messages

Pesan adalah isi, informasi, atau pernyataan yang didukung oleh lambang yang akan disampaikan oleh komunikator pada komunikan.

3. Komunikan/receiver/penerima

Komunikan adalah pihak yang menerima informasi dan memberikan umpan balik kepada komunikator.

4. Media/chanel/saluran

Media adalah sarana yang digunakan selama terjadinya proses komunikasi.

5. Efek

Efek adalah dampak yang terjadi akibat adanya pengaruh dari pesan.

Komponen pesan dan media dalam suatu proses komunikasi, dikolaborasikan menjadi satu bentuk yang lebih kompleks, yang dikenal sebagai berita. Secara umum terdapat tiga macam bentuk berita, yaitu:

1. Berita yang bersifat audible, yaitu berita yang dapat didengar baik secara langsung maupun tidak langsung (telepon, radio, lonceng, sirine). Bentuk berita seperti ini jarang dijumpai dalam klub kebugaran, karena untuk memperoleh informasi anggota klub tidak berkomunikasi dengan media tetapi langsung bertemu dengan sumber informasi. Sumber informasi tersebut di antaranya: dokter klub, instruktur, petugas administrasi atau sesama anggota klub itu sendiri.

Meskipun demikian pada saat-saat tertentu, bentuk berita audible juga digunakan, misalnya kaset, pun tidak memiliki tujuan untuk berkomunikasi tetapi lebih sebagai pengiring gerakan saat senam aerobik. Atau ada pihak lain yang mencari informasi mengenai klub kebugaran tersebut dan keperluan lain yang sifatnya eksternal, maka akan menggunakan telepon atau media lainnya.

2. Berita yang bersifat visual, yaitu berita yang dapat dilihat, yang berbentuk tulisan, poster, gambar-gambar. Di dalam sebuah klub kebugaran bentuk informasi yang bersifat visual biasanya dapat dengan mudah ditemui, misalnya: petunjuk arah (toilet, locker, dan mushola), peraturan

Pengaruh Komunikasi Efektif dan Pelayanan Prima bagi Wanita ... (Eka Novitas Indra) 
penggunaan alat, gambar petunjuk cara melakukan peregangan, jadwal konsultasi, dan data anggota dalam komputer.

3. Berita yang bersifat audio visual, yaitu berita yang dapat didengar dan dilihat.

Berita audio visual untuk saat ini dipandang sebagai media informasi yang paling modern, informasi yang didapat akan lebih jelas dan kemungkinan terjadinya salah persepsi lebih kecil. Jenis berita audio visual yang sering ditemui di klub kebugaran adalah video penggunaan alat dan video senam aerobik.

Dalam suatu proses komunikasi, media tidak selalu diperlukan oleh komunikator, artinya komunikasi dapat dilakukan secara langsung dan isi pesan komunikator sampai pada komunikan tanpa melalui media, feedback dari komunikan pada komunikator juga disampaikan secara langsung tanpa menggunakan media. Proses komunikasi seperti ini disebut komunikasi langsung atau face to face/direct communication.

Jenis komunikasi langsung dominan terjadi dalam suatu klub kebugaran, komunikasi yang terjadi antara petugas administrasi, instruktur, dan anggota terjadi secara langsung tanpa melalui media.

\section{Proses Komunikasi}

Suatu proses komunikasi melibatkan tiga komponen utama, berikut bagan paling sederhana terjadinya komunikasi:

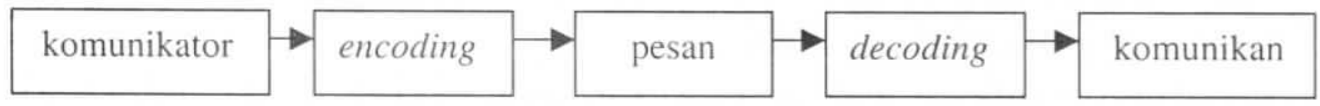

Sebelum mengirimkan pesan komunikator akan terlebih dahulu mengemasnya dalam bentuk yang dianggap sesuai, dapat diterima dan dimengerti oleh komunikan. Pengemasan pesan ini disebut sebagai encoding. Encoding secara harfiah berarti memasukkan dalam kode. Dengan proses encoding, komunikator memasukkan atau mengungkapkan perasaannya ke dalam kode atau lambang dalam bentuk kata-kata atau nonkata, misalnya raut wajah atau gerak tubuh. Setelah pesan sampai pada komunikan, apabila ada umpan balik komunikan akan bertindak sebagai komunikator, yaitu

MEDHKORA Vol. I, No. 2, Oktober 2005: 186-201. 
memasukkan kode yang disebut decoding untuk disampaikan kembali pada komunikator.

\section{Macam-macam Komunikasi}

Meskipun komunikasi menyangkut perilaku manusia, tidak semua perilaku manusia itu adalah komunikasi. Menurut Pace dan Faules dikutip oleh Deddy Mulyana dalam bukunya Ilmu Komunikasi: Suatu Pengantar (2005: 59) perbedaan tersebut sederhana namun rumit. Sebagai contoh apakah memancing ikan di kolam, bernyanyi sendiri di kamar mandi, memasukkan sepucuk surat ke kotak surat, dan mengetik makalah seminar di komputer merupakan bentuk-bentuk komunikasi?

Jawaban atas pertanyaan-pertanyaan tersebut bergantung pada bagaimana orang mendefinisikan komunikasi. Menurut Pace dan Faules terdapat dua bentuk umum tindakan yang dilakukan orang yang terlibat dalam komunikasi, yaitu penciptaan pesan dan penafsiran pesan. Pesan ini tidak selalu dalam bentuk kata-kata, misalnya seorang instruktur klub kebugaran dalam memberikan informasi penggunaan alat tidak selalu dengan kata-kata (deskriptif) namun bisa juga dilakukan dengan pertunjukan (display) atau yang lazim disebut pesan nonverbal.

Secara garis besar macam komunikasi terbagi menjadi dua bagian, kedua bentuk komunikasi ini yang selalu kita lakukan dalam keseharian, yaitu:

1. Komunikasi Verbal

Komunikasi verbal adalah proses komunikasi yang pesannya dapat secara langsung dimengerti oleh komunikan, secara umum dapat dikatakan bahwa bentuk pokok komunikasi verbal adalah kata-kata, yang disampaikan secara lisan maupun dalam bentuk tulisan.

2. Komunikasi Nonverbal, terdiri atas: (a) bahasa tubuh, (b) sentuhan, (c) parabahasa, (d) penampilan fisik, (e) bau-bauan, (f) artefak, (g) konsep waktu, dan (h) orientasi ruang dan jarak pribadi.

Kepuasaan anggota dalam suatu klub kebugaran adalah prioritas utama, dan hanya dapat terwujud apabila melayani secara prima sudah menjadi budaya. Komuniksai yang baik dan efektif merupakan ujung tombak tercapainya tujuan tersebut. Tidak semua orang dapat berkomunikasi dengan

Pengaruh Komunikasi Efektif dan Pelayanan Prima bagi Wanita ... (Eka Novitas Indra) 
baik, selain proses belajar, dibutuhkan suatu strategi untuk dapat berkomunikasi secara efektif.

\section{Strategi Komunikasi}

Strategi komunikasi pada hakikatnya merupakan paduan dari perencanaan komunikasi dan manajemen komunikasi. Strategi komunikasi harus didukung oleh teori, sebab teori merupakan pengetahuan berdasarkan pengalaman yang sudah dibuktikan kebenarannya.

Seorang ahli komunikasi Harold. D. Lasswell yang juga dikutip oleh Deddy Mulyana dalam bukunya. Ilmu Komunikasi: Suatu Pengantar (2005: 136) mengemukakan teori komunikasi yang kemudian dalam perkembangannya sangat populer dengan sebutan teori Lasswell. Lasswell mengatakan bahwa cara terbaik untuk menerangkan kegiatan komunikasi ialah dengan menjawab pertanyaan "who says What in Which Channel To Whom With What Effect?"

Dari pernyataan tersebut tersirat bahwa segala proses komunikasi dipertautkan dengan komponen-komponen yang merupakan jawaban terhadap pertanyaan Lasswell tersebut:

1. Who? (siapakah komunikatornya?)

2. Says what? (pesan apa yang dinyatakan?)

3. In which channel? (media apa yang dipergunakan?)

4. To whom? (siapa komunikannya?)

5. With what effect? (efek apa yang diharapkan?)

Rumus Lasswell tersebut tampaknya sangat sederhana, tetapi jika dikaji lebih jauh pertanyaan "efek apa yang diharapkan", secara implisit mengandung pertanyaan lain yang perlu dijawab dengan saksama, yaitu:

6. When? (kapan dilaksanakannya?)

7. How? (bagaimana pelaksanaannya?)

8. Why? (mengapa dilaksanakan demikian?)

Tambahan pertanyaan tersebut dalam strategi komunikasi sangat penting karena pendekatan terhadap efek yang diharapkan dari suatu kegiatan bisa bermacam-macam, di antaranya:

1. Information (informasi).

Mrebifiend Vol. I, No. 2, Oktober 2005: 186-201. 


\section{Persuasion (persuasi). \\ 3. Instruction (instruksi).}

\section{Ruang Lingkup Komunikasi}

Ruang lingkup komunikasi yang kita bahas adalah buman communication (komunikasi manusia), jadi dalam proses komunikasi melibatkan manusia sebagai subjek dan objeknya. Lingkup komuniksai sangat berpengaruh terhadap proses penerimaan pesan, yang akan semakin menyempit sejalan dengan peningkatan jumlah orang yang terlibat.

Ruang lingkup komunikasi terdiri atas empat kelompok, yaitu:

1. Komunikasi intrapersonal (intrapersonal communication)

Komunikasi intrapersonal adalah suatu bentuk komunikasi yang terjadi secara intern dalam individu.

2. Komunikasi interpersonal (interpersonal communication)

Komunikasi interpersonal adalah bentuk komunikasi yang terjadi antara dua individu sebagai komunikan dan komunikator. Komunikasi jenis ini dianggap paling efektif dalam hal upaya mengubah sikap, pendapat atau perilaku seseorang karena sifatnya dialogis (berupa percakapan), umpan balik dapat langsung diterima oleh komunikator saat proses komunikasi masih berjalan.

Misalnya pada saat seorang konsultan klub memberikan arahan tentang pelaksanaan program latihan pada seorang anggota klub.

3. Komunikasi kelompok (small group communication)

Komunikasi kelompok adalah ruang lingkup komunikasi yang mungkin paling sering terjadi dalam suatu klub kebugaran, selain komunikasi interpersonal. Komunikasi kelompok termasuk komunikasi langsung, karena komunikator dan komunikan berada dalam satu tempat dengan situasi dapat saling melihat secara langsung. Misalnya, pada saat seorang instruktur di suatu klub kebugaran memperkenalkan cara pemakaian alat latihan beban kepada beberapa orang anggotanya. Instruktur dapat mengetahui umpan balik secara langsung apabila instruksi yang disampaikan dapat dimengerti, sedangkan apabila disadari bahwa instruksi tidak diterima dengan baik, instruktur dapat langsung mengubah gaya penyampaiannya.

Pengaruh Komunikasi Efektif dan Pelayanan Prima bagi Wanita ... (Eka Novitas Indra) 
4. Komunikasi massa (mass communication)

Terdapat banyak sekali definisi komunikasi massa yang dikemukakan olah para ahli. Devito memberikan dua definisi komunikasi massa dikutip dari buku Komunikasi Massa (2004: 10-11), yaitu: komunikasi massa adalah komunikasi yang ditujukan kepada massa, kepada khalayak yang luar biasa banyaknya. Difinisi yang lain mengatakan komunikasi massal adalah komunikasi yang disalurkan oleh pemancar yang bersifat audio, visual, maupun audio visual.

Komunikasi massa menurut Jay Back dan Whitney yang dikutip dari buku Komunikasi Massa (2004: 11) adalah sebuah proses penyebarluasan pesan-pesan yang diproduksi secara massal kepada massa penerima yang bersifat anonim, dan heterogen.

Kelancaran proses komunikasi massa sangat bergantung pada peralatan teknis yang modern, karena khalayak yang ingin dijangkau dalam jumlah yang sangat besar dan dipisahkan oleh jarak dan waktu. Jenis alat komunikasi massa, dapat dilihat pada gambar berikut:

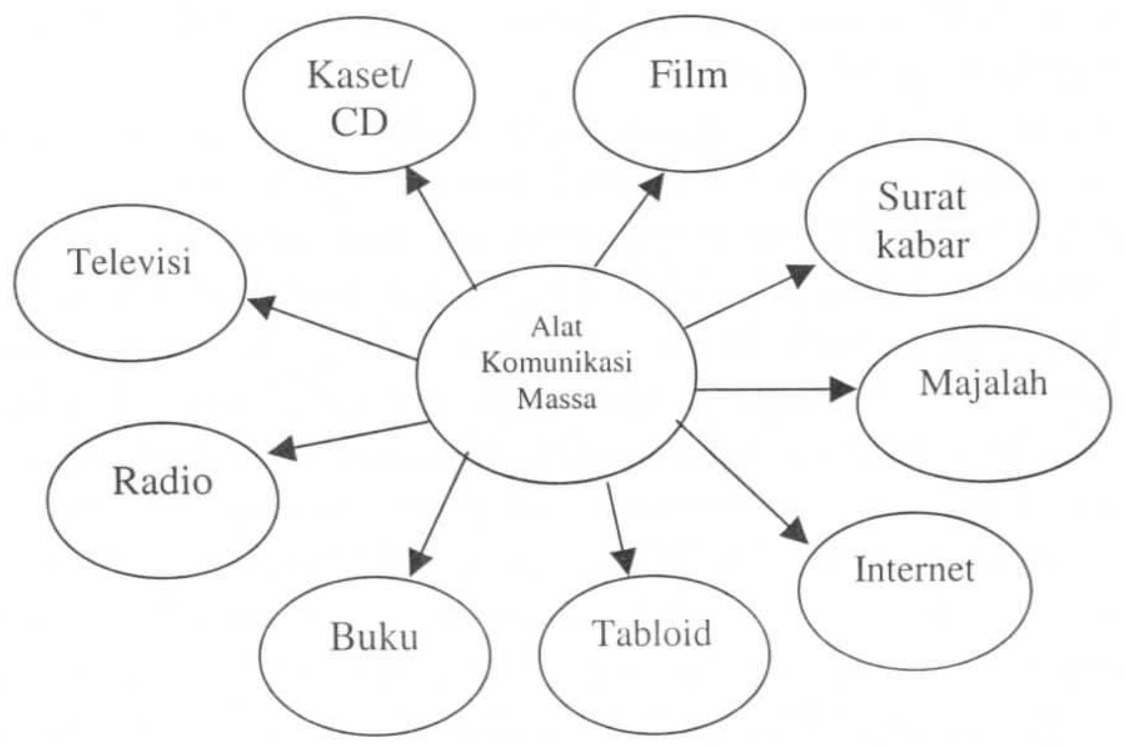

Gambar 1. Alat Komunikasi Massa

Wenvifuedina Vol. I, No. 2, Oktober 2005: 186-201. 
Dalam komunikasi massa, komunikatornya adalah organisasi sosial yang mampu memproduksi pesan dan mengirimkannya secara serempak ke sejumlah orang banyak yang terpisah. Komunikator dalam komunikasi massa biasanya media massa. Media massa tersebut adalah organisasi sosial, sebab individu di dalamnya punya tanggung jawab yang sudah dirumuskan seperti dalam sebuah organisasi.

Dari sekian banyak definisi yang dikemukakan ada benang merah kesamaan yang ditemukan, yaitu pada dasarnya komunikasi massa adalah komunikasi melalui media massa (cetak dan elektronik), dan dalam komunikasi massa tidak ada tatap muka antarpenerima pesan.

\section{PELAYANAN PRIMA}

Pelayanan prima merupakan terjemahan dari istilah excellent service yang secara harafiah berarti pelayanan yang sangat baik, karena sesuai dengan standar pelayanan yang berlaku atau dimiliki oleh instansi yang memberikan pelayanan. Jadi pelayanan prima adalah bentuk pelayanan yang sesuai dengan harapan pelanggan. Pelayanan pada dasarnya adalah kegiatan yang ditawarkan oleh suatu organisasi, perusahaan atau perorangan kepada pihak lain (konsumen). Pelayanan dapat dibedakan menjadi tiga kelompok, yaitu:

1. Core service

Adalah pelayanan yang ditawarkan pada konsumen, yang merupakan produk utamanya. Misalnya, dalam suatu klub kebugaran wajib memiliki instruktur untuk melayani anggotanya.

2. Facilitating service

Adalah fasilitas pelayanan tambahan bagi konsumen selain produk utama, tetapi sifatnya wajib. Selain harus memiliki instruktur klub kebugaran juga harus memiliki fasilitas ruang ganti dan toilet, meskipun termasuk fasilitas tambahan tetapi wajib dipenuhi.

3. Supporting service

Seperti pada facilitating service, supporting service juga merupakan pelayanan tambahan (pendukung) untuk meningkatkan nilai pelayanan, atau membedakan dengan pelayanan-pelayanan dari pihak pesaingnya. Misalnya, fasilitas kafe dan mushola di suatu klub kebugaran.

Pengaruh Komunikasi Efektif dan Pelayanan Prima bagi Wanita ... (Eka Novitas Indra) 


\section{Tujuan Pelayanan Prima}

Tujuan pelayanan prima adalah memberikan pelayanan yang dapat memenuhi dan memuaskan konsumen. Pada sektor swasta/bisnis, dalam hal ini klub kebugaran sebagai perusahaan yang menjual produk dan jasa (hospitality industry), selalu bertujuan dan berorientasi pada keuntungan perusahaan (profite oriented)

\section{Prinsip-prinsip Pelayanan Prima}

Dalam menjalankan suatu proses pelayanan agar efektif dan efisien, sebaiknya dilakukan berdasarkan prinsip-prinsip sebagai berikut: (1) kesederhanaan, (2) kejelasan dan kepastian, (3) keamanan, (4) keterbukaan, (5) efisien, (6) ekonomis, (7) keadilan yang merata, (8) ketepatan waktu, dan (9) penataan dan perbaikan.

\section{Mutu Pelayanan Prima}

Dalam menjaga mutu pelayanan, ada beberapa hal penting yang harus diperhatikan oleh para penjual produk dan jasa, yaitu:

1. Konsep mendahulukan kepentingan pelanggan

Pelayanan prima adalah pelayanan yang memuaskan pelanggan, salah satu indikatornya adalah tidak adanya keluhan dari pelanggan. Untuk itu, sebagai pemberi pelayanan perlu mengetahui sumber-sumber keluhan pelanggan dan mengetahui cara-cara mengatasi keluhan tersebut.

2. Pelayanan dengan sepenuh hati

Pada hakikatnya konsumen tidak hanya membeli produk, tetapi mereka juga membeli pelayanan. Ini merupakan falsafah bisnis dalam upaya memberikan pelayanan prima dengan tujuan mendapatkan keuntungan untuk jangka waktu panjang.

3. Budaya pelayanan prima

Menganggap pelayanan prima sebagai suatu budaya, berarti melakukan kegiatan pelayanan sebagai suatu hal yang membanggakan dengan nilai luhur yang dijunjung tinggi.

4. Sikap pelayanan prima

Sikap pelayanan prima berarti pengabdian yang tulus terhadap bidang kerja dan yang paling utama adalah tanggung jawab atas suatu pekerjaan.

Vol. I, No. 2, Oktober 2005: 186-201. 
5. Sentuhan pribadi pelayanan prima

Pelayana prima sangat memperhatikan individu sebagai pribadi yang unik dan menarik.

6. Pelayanan prima sesuai dengan pribadi prima

Konsep pribadi prima meliputi unsur-unsur kepribadian, penampilan, perilaku, dan komunikasi yang prima. Seseorang dapat dikatakan memiliki pribadi prima apabila tampil ramah, sopan dan menghormati orang lain, percaya diri, rapi, ceria, memaafkan, mampu bergaul dengan orang lain, bersikap wajar, dapat menyenangkan orang lain, dan mau terus belajar memperbaiki diri.

\section{Komponen Pelayanan Prima}

Terdapat delapan komponen pelayanan prima, yaitu:

\section{Information}

Proses suatu pelayanan yang berkualitas dimulai dari komponen adanya informasi dari produk dan jasa yang diperlukan. Penyediaan informasi yang tepat dan akurat akan memberikan kemudahan bagi calon konsumennya.

2. Consultation

Setelah memperoleh informasi yang diperlukan, biasanya konsumen akan memutuskan akan menggunakan atau tidak produk yang ditawarkan.

3. Undertaking

Keyakinan yang diperoleh anggota melalui konsultasi akan menggiring pada tindakan untuk menggunakan produk dan jasa yang dijual oleh suatu klub kebugaran.

4. Hospitality

Anggota klub kebugaran akan memberikan penilaian terahadap sikap ramah dan sopan dari instruktur maupun karyawan lain, ruang tunggu yang nyaman, kafe untuk makan dan minum, hingga tersedianya ruang ganti dan toilet yang bersih.

5. Caretaking

Latar belakang konsumen yang beraneka ragam akan menuntut pelayanan yang berbeda pula. Misalnya, anggota klub yang bermobil menginginkan tempat parkir yang luas.

Pengaruh Komunikasi Efektif dan Pelayanan Prima bagi Wanita ... (Eka Novitas Indra) 
6. Exception

Beberapa anggota (konsumen) kadang-kadang menginginkan pengecualian kualitas pelayanan, sebagai penjual jasa tentu saja harus menguasai hal berkait situasi tersebut.

7. Billing

Salah satu titik rawan dari suatu proses pelayanan pada suatu instansi adalah administrasi. Penjual harus sangat memperhatikan hal yang terkait dengan segala proses administrasi, baik pendataan, maupun pembayaran, ditinjau dari mekanismenya atau pengisian formulir transaksi.

8. Payment

Pada akhir pelayanan, harus disediakan fasilitas pembayaran berdasarkan pada keinginan pelanggan. Misalnya, di sebuah klub kebugaran iuran bulanan anggota tidak hanya dapat dibayarkan dengan kas, tetapi juga dapat dilakukan dengan menggunakan kartu kredit.

\section{MOTIVASI WANITA UNTUK MELAKUKAN LATIHAN BEBAN}

Motivasi adalah suatu usaha yang disadari untuk menggerakan, mengarahkan dan menjaga tingkah laku seseorang agar ia terdorong untuk bertindak melakukan sesuatu sehingga mencapai hasil atau tujuan tertentu. Definisi motivasi yang lain dikemukakan oleh McDonald, yang dikutip oleh Oemar Hamalik (1992: 173) "motivation is a energy change within the person characterized by affective arousal and anticipatory goal reactions." Dari pernyataan tersebut, dapat disimpulkan bahwa motivasi adalah satu faktor penting bagi seseorang untuk dapat melakukan suatu tindakan yang sesuai dengan cita-cita dan tujuan yang diharapkannya.

Motivasi merupakan pendorong bagi perbuatan seseorang, menyangkut soal mengapa seseorang berbuat demikian dan apa tujuannya sehingga ia berbuat demikian. Untuk mencari jawaban tersebut, mungkin harus dicari apa yang mendorongnya (faktor internal) dan perangsang atau stimulus (faktor eksternal) yang menariknya untuk melakukan perbuatan itu.

Dari definisi-definisi yang telah disebutkan di atas, dapat ditarik kesimpulan secara umum bahwa yang dimaksud dengan motivasi adalah

MEDUHU⿴囗十⺝木 Vol. I, No. 2, Oktober 2005: 186-201. 
segala sesuatu yang mendorong seseorang untuk melakukan sesuatu dengan tujuan tertentu baik itu yang bersifat intrinsik maupun yang bersifat ekstrinsik.

\section{Proses Motivasi}

Motivasi, pelaksanaan kegiatan, dan tujuan merupakan tiga komponen yang berkaitan erat dan membentuk suatu kesatuan yang disebut proses motivasi. Proses motivasi itu sendiri meliputi tiga langkah (Nana S. Sukmadinata, 2003: 62), yaitu:

1. Adanya suatu kondisi yang terbentuk dari tenaga-tenaga pendorong (desakan, motif, kebutuhan, dan keinginan) yang menimbulkan suatu ketegangan atau tension.

2. Berlangsungnya kegiatan atau tingkah laku yang diarahkan kepada pencapaian sesuatu tujuan yang akan mengendurkan atau menghilangkan ketegangan.

3. Pencapaian tujuan dan berkurangnya atau hilangnya ketegangan.

\section{Macam-macam Motivasi}

Sardiman A.M (200: 89-90) membagi motivasi ke dalam dua kelompok utama, yaitu motivasi intrinsik dan motivasi ekstrinsik,

1. Motivasi Intrinsik

Motivasi intrinsik adalah motif-motif yang menjadi aktif atau berfungsinya tidak perlu dirangsang dari luar, karena dalam diri setiap individu sudah ada dorongan untuk melakukan sesuatu. Dilihat dari segi tujuan kegiatan yang dilakukannya, maka yang dimaksud dengan motivasi intrinsik adalah ingin mencapai tujuan yang terkandung di dalam perbutan belajar itu sendiri.

Motivasi intrinsik dapat juga dikatakan sebagai bentuk motivasi yang di dalamnya aktivitas belajar dimulai dan diteruskan berdasarkan suatu dorongan dari dalam diri dan secara mutlak berkait dengan aktivitas belajarnya. Jadi, memang motivasi itu muncul dari kesadaran diri sendiri dengan tujuan secara esensial, bukan sekedar simbol dan seremonial.

2. Motivasi Ekstrinsik

Motivasi ekstrinsik adalah motif-motif yang aktif dan berfungsinya

Pengaruh Komunikasi Efektif dan Pelayanan Prima bagi Wanita ... (Eka Novitas Indra) 
karena ada perangsangan dari luar. Dilihat dari segi tujuan kegiatan yang dilakukannya tidak secara langsung bergayut dengan esensi apa yang dilakukannya. Oleh karena itu, motivasi ekstrinsik dapat juga dikatakan sebagai bentuk motivasi yang di dalamnya aktivitas belajar dimulai dan diteruskan berdasarkan dorongan dari luar yang tidak secara mutlak berkaitan dengan aktivitas belajarnya.

\section{Tujuan Motivasi}

Tujuan motivasi adalah untuk menggerakkan atau menggugah seseorang agar timbul keinginan dan kemauan untuk melakukan sesuatu, sehingga dapat memperoleh hasil atau mencapai tujuan tertentu. Motivasi dan tujuan seseorang untuk melakukan latihan dalam suatu klub kebugaran tentu saja berlainan. Sebagaimana dikemukakan oleh Ngalim Purwanto (1991: 71) bahwa motivasi adalah suatu usaha yang disadari untuk menggerakan, mengarahkan, dan menjaga tingkah laku seseorang agar ia terdorong untuk bertindak melakukan sesuatu, sehingga mencapai hasil atau tujuan tertentu.

Faktor-faktor yang mempengaruhi motivasi seseorang adalah umur, kondisi fisik, latar belakang sosial ekonomi, dan kekuatan inteligensi yang juga harus dipertimbangkan. Motivasi itu kemudian menjadi pendorong bagi seseorang untuk melakukan suatu kegiatan, hal tersebut menyangkut soal mengapa seseorang berbuat demikian.

Hasil suatu penelitian yang dilakukan oleh penulis di sebuah fitness centre khusus wanita di Yogyakarta, menunjukkan bahwa motivasi yang berasal dari diri sendiri (intrinsik) lebih dominan mempengaruhi anggota klub kebugaran secara keseluruhan dalam melaksanakan program latihan daripada motivasi yang berasal dari luar diri sendiri (ekstrinsik). Perolehan angka hasil penelitian adalah sebagai berikut: motivasi intrinsik memberikan pengaruh sebesar $63,88 \%$, sedangkan motivasi ekstrinsik hanya sebesar $36,12 \%$.

Berdasarkan angka persentase hasil penelitian tersebut, motivasi seorang wanita untuk bergabung dan mengikuti program latihan di klub kebugaran tidak hanya ada dorongan dari dalam diri sendiri, tetapi juga dipengaruhi oleh faktor dari luar (eksternal) yang persentase hasilnya cukup

Mituketif Vol. I, No. 2, Oktober 2005: 186-201. 
signifikan dikaitkan dengan perolehan profit perusahaan jangka panjang. Komunikasi efektif sebagai bagian dari pelayanan prima dalam suatu klub kebugaran adalah dua hal pokok yang memberi motivasi seseorang secara ekstrinsik.

\section{PENUTUP}

Berdasarkan uraian tersebut di atas, dapat diambil kesimpulan bahwa keberhasilan pencapaian tujuan latihan seseorang dalam suatu klub kebugaran tidak hanya bergantung pada rancangan program latihan yang diberikan oleh instruktur, tetapi juga dipengaruhi oleh keseriusan dan motivasi anggota itu sendiri dalam melaksanakan latihan.

Motivasi seseorang terdiri atas motivasi intrinsik dan motivasi ekstrinsik. Motivasi intrinsik relatif lebih sulit dipengaruhi oleh faktor eksternal. Pengaruh pelayanan prima dan komunikasi efektif cukup signifikan terhadap peningkatan motivasi ekstrinsik seorang khususnya wanita untuk bergabung dan mengikuti program latihan di klub kebugaran.

\section{DAFTAR PUSTAKA}

Deddy Mulyana. (2004). Komunikasi Efektif. Bandung: PT. Remaja Rosda Karya. Karya.

Endang Lestari dan MA. Maliki. (2003). Komunikasi yang Efektif. Jakarta: Lembaga Administrasi Negara.

Nana. S. Sukamadinata. (2003). Landasan Psikologi Proses Pendidikan. Bandung: PT. Remaja Rosda Karya.

Ngalim Purwanto. (1991). Psikologi Pendidikan, Edisi III. Bandung: PT. Remaja Rosda Karya.

Nurudin. (2004). Komunikasi Massa. Yogyakarta: Pustaka Pelajar.

Oemar Hamalik. (1992). Psikologi Belajar Mengajar. Bandung: Sinar Baru.

Sardiman AM. (2001). Interaksi dan Motivasi Belajar Mengajar. Jakarta: PT. Raja Grafindo. 